\title{
VILA BELA DA SANTÍSSIMA TRINDADE: MANISFESTAÇÃO DE FÉ E CULTURA
}

\author{
Anne Caroline de Brito Berlandi ${ }^{1}$ \\ Veruska Pobikrowska Tardivo ${ }^{2}$ \\ Renata Barros Abelha Kabeya ${ }^{3}$
}

RESUMO: Este trabalho tem por objetivo o estudo e análise da manifestação de cultura e fé no município de Vila Bela da Santíssima Trindade, exemplificado no evento Festança de Vila Bela que ocorre periodicamente entre o primeiro e o segundo semestre do ano. Sendo de caráter internacional, move o turismo e economia na região, reafirmando a cada ano suas origens e crenças. A partir de estudos, visitas in loco e auxilio de alguns moradores foi possível realizar o referente artigo que demonstra todo o fervor religioso e cultural, ratificando a tradição passada durante anos por seus descendentes. Realizamos estudos e discussões que reafirmam a importância da conservação da cultura e tradição, seja por meio de crenças, rituais ou fé. No caso de Vila Bela da Santíssima Trindade, há a combinação de todos estes elementos, juntando crença católica e cultura africana, em meio a um ambiente que além de sediar a primeira capital de Mato Grosso, foi palco desde o início de manifestações dos escravos em luta por ideais de liberdade e justiça. A fé nas tradições iniciadas nos quilombos não foi esquecida, sendo vividas e sentidas todo o ano, trazendo lembranças do sofrimento e da beleza de suas raízes.

\footnotetext{
${ }^{1}$ Acadêmica do $9^{\circ}$ semestre do curso de Arquitetura e Urbanismo da Universidade do Estado do Mato Grosso, UNEMAT. E-mail: anne.berlandi@hotmail.com

${ }^{2}$ Professora Msc. Orientadora, Departamento de Arquitetura e Urbanismo da Universidade do Estado de Mato Grosso, UNEMAT. E-mail: veruska.tardivo@yahoo.com.br

${ }^{3}$ Professora Msc. de Sociologia, Departamento de Matemática da Universidade do Estado de Mato Grosso, UNEMAT. E-mail: reabelha@terra.com.br
} 
Palavras-chaves: cultura, tradição e religião

\section{INTRODUÇÃO}

O município de Vila Bela da Santíssima Trindade possui cultura e costumes peculiares, trazidas pelos antigos escravos e cultivadas por seus descendentes, e neste sentido seus moradores, a fim de representarem e homenagearem todo o fervor religioso e cultural, promovem festividades como a Festança de Vila Bela SS. Trindade, mesclando cultura africana e a crença católica.

O objetivo deste artigo é apresentar e analisar toda essa manifestação de fé que ocorre anualmente na primeira capital de Mato Grosso, fazendo com que todo o município anualmente abra as portas para os rituais, festividades, cantos e danças ao decorrer de todo o espaço territorial do município.

A realização deste estudo, que por sua vez segue um desenvolvimento exploratório, tem por ideal levantar informações que tragam o embasamento necessário para a realização da referente temática. Portanto a metodologia utilizada foi o levantamento de materiais bibliográficos existentes e compatíveis ao tema, com o intuito de elaborar e articular a argumentação teórica; visita in loco a fim de se obter dados específicos e precisos sobre a vida e movimento da cidade no período da Festança; depoimento de alguns moradores; e a análise dos dados coletados.

Discutidos alguns conceitos e teorias a respeito de tradição, cultura, crença e manifestação de fé, tornando possível a análise da importância de atos de cidadania e integração social, em meio ao que devemos acreditar quanto ao resgate de valores humanos.

Descreveremos também toda a trajetória e história da cidade de Vila Bela Santíssima Trindade, relatando sua fundação, localização, território e população, a fim de se apresentar a cidade e mostrar a sua relevância perante o estado de Mato Grosso. 
A Festança de Vila Bela da Santíssima Trindade é relatada para que se tenha conhecimento do objeto estudado, onde veremos todas as etapas desta grande festividade que move e uni os cidadãos do município, tais como os rituais, danças comidas típicas e cantos. Por fim faremos as analises finais, seguido das ultimas considerações a respeito de todos os dados coletados.

\section{TRADIÇÃO, CULTURA E RELIGIÃO}

O conceito de cidade é definido como um espaço territorial que abrange um conglomerado de moradores e visitantes juntamente a casas, ruas, edifícios, monumentos etc. A organização e a caracterização dos espaços e da vida urbana ocorrem através dessas pessoas e objetos, que agregam simbolismos aos centros urbanos, como odores, eventos, cultura, sabores, manifestações, ritmo, entre outros, os diferenciando entre si (CAVALCANTE, 2007).

O conhecimento das necessidades de uma população e da vida urbana contida nela, permite buscar meios de um planejamento urbano que incorpore infra-estrutura, cultura e interação social.

Rodrigues (2008) define a cultura como a "somatória de costumes, tradições e valores - é um jeito próprio de ser, estar e sentir o mundo, 'jeito' este que leva o indivíduo a fazer, ou a expressar-se, de forma característica (...)". O 'ser' divide o mesmo espaço com o 'pertencer', seja a um grupo, uma família, um povo, alguma fé ou lugar. A cultura é um forte agente de identificação, seja de âmbito social ou pessoal, associando fatores da sociedade e de eras, onde mudanças culturais expressivas apontam evoluções de povos.

A cultura pode resgatar a cidadania, fortalecer a identidade pessoal, integrar a sociedade ao meio em que vive, trazendo bens comuns entre os indivíduos, a saúde mental e o sentimento feliz de ser útil. Portanto, se faz necessário o cultivo, a aplicação, difusão, ou seja, manifestar e integrar cultura à sociedade, fazendo com que os seres humanos se tornem mais ricos quanto as suas potencialidades. 
Eventos culturais muitas vezes estão interligados a manifestações religiosas, seja por algum acontecimento histórico marcante, ou por graças alcançadas. Elas por sua vez movem enormes seguidores, que acreditam nas vantagens por meio da fé, trazendo esperança e união entre os fiéis.

Coelho (2007) expõe de forma crítica sua opinião sobre o que é a crença e fé, apontando que toda tradição religiosa implica na prática de devoção e também de transformação, dizendo ainda que devoção é o ato de confiar mais em nós mesmos e nos caminhos que se escolhe seguir, sendo transformação 0 ato de se praticar as coisas que este caminho nos impõe.

\section{VILA BELA DA SANTíSSIMA TRINDADE: A PRIMEIRA CAPITAL DE MATO GROSSO.}

Vila Bela Santíssima Trindade localiza-se na parte oeste de Mato Grosso (Figura 1), ocupa uma área de $13.631 \mathrm{~km}^{2}$ e estima 14.523 habitantes segundo dados do IBGE (2009). Ela faz limite com a cidade de Comodoro ao norte, ao leste com os municípios de Pontes e Lacerda e Nova Lacerda e limita-se com a República da Bolívia ao Sul e Oeste. Situa-se na bacia amazônica, a 198 metros acima do nível do mar (LIMA, 2000, P. 21).

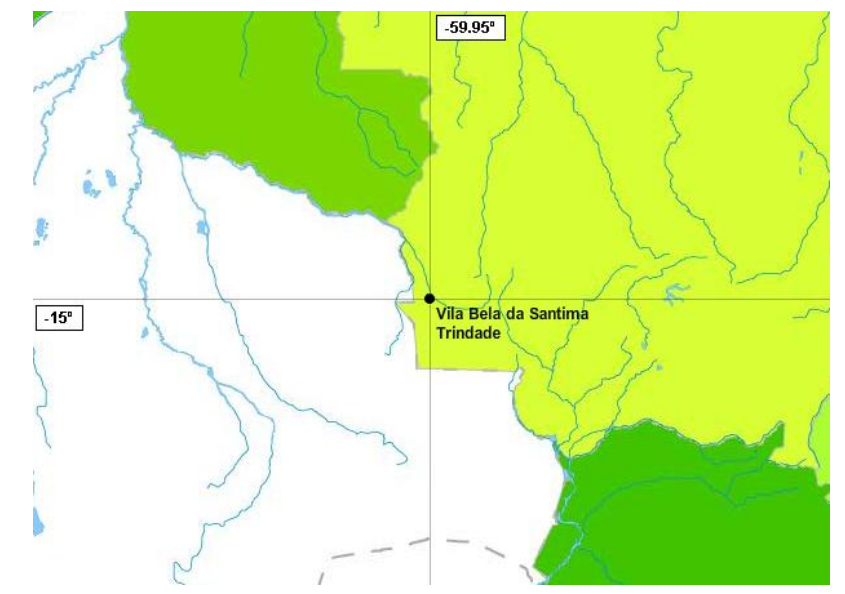

Figura 1: Localização de Vila Bela SS. Trindade.

Fonte: IBGE, 2007. 
O relevo possui características do cerrado e da Amazônia, sendo marcado por extensos chapadões. A serra Ricardo Franco é a que possui maior ênfase, localizado na divisa de Vila Bela e Republica da Bolívia. O clima predominante é o quente e semiúmido, sendo marcante pelo período de seis meses de cheia e seis meses de seca, fato este que influenciou a decadência da cidade como capital, posteriormente, abordado neste artigo (LIMA, 2000, P. 21).

A cidade possui grande importância na história da formação do estado de Mato Grosso. No período provincial, esta região foi escolhida para sediar a capital do estado por Dom Rolim de Moura em 19 de março de 1752, devido à descoberta de jazidas de ouro no local e sua localização sobre parte do Rio Guaporé, sendo assim um ótimo lugar para se difundir a economia do estado, idealizado pela coroa portuguesa a partir de um plano de desenvolvimento e de traçado urbano, como visto na figura 2 (FACCHINETTO, 2009, p. 1).

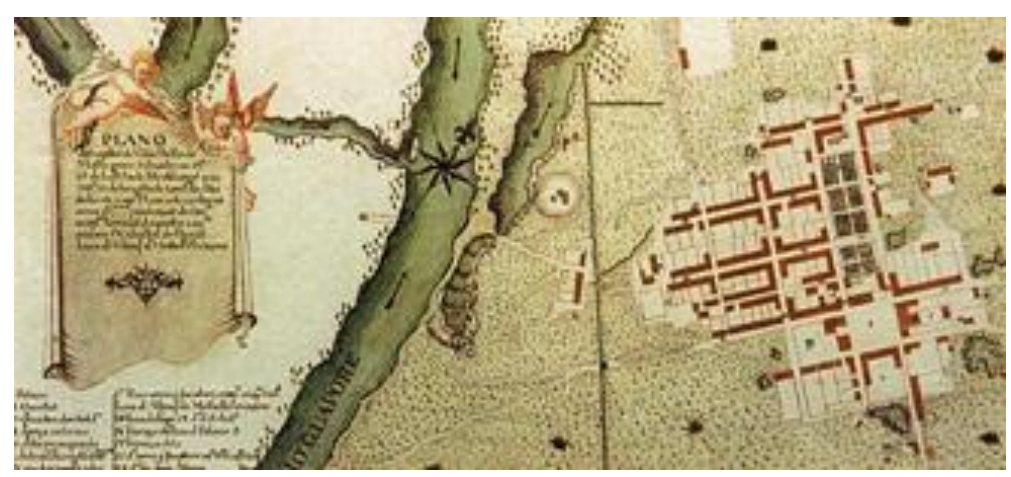

Figura 2: plano de traçado idealizado pela coroa portuguesa para Vila Bela. Fonte: FACCHINETTO, 2009.

Poucos anos após sua fundação, a cidade evidenciou não ser mais adequada, devida sua falta de salubridade, comum obtenção de doenças na população e o intenso trabalho escravo, que juntamente aos maus tratos, reduzia vida útil desta mão de obra. $\mathrm{A}$ cidade então foi considerada uma "terra doentia". O fato do arrecadamento sobre as minas de ouro ser instável, o comércio ser incerto pela distância da cidade afetando assim a chegada de mercadorias, a tensão a dominar a população pela resistência do povo indígena sobre o território e a produção agrária condenada devido às expressivas cheias em um período e a seca espaçada em outro, fez com que a transferência da capital do 
Estado para outro lugar fosse inevitável, posteriormente se fixando na atual cidade de Cuiabá. Os brancos da época diziam que só os negros poderiam permanecer na região, pois eram mais fortes sendo menos suscetíveis à obtenção de doenças. Os escravos então foram "largados" no município, disseminando ali seus ideais de liberdade e suas culturas raízes (FACCHINETTO, 2009, p. 2).

Lima (2000) relata que a população negra de Vila Bela ainda possui a lembrança de toda a atrocidade da escravidão, onde os maus tratos e o trabalho intenso nos garimpos trouxeram-lhe essas marcas e revoltas, decorrentes em todo o Brasil. Os negros resistiam pela liberdade e resgate do seu corpo, por tanto várias lutas ocorriam na época a fim de findar o regime atroz onde se encontravam. A solução muitas vezes era a morte prematura, suicídio e fuga, sendo o ultimo o promissor dos quilombos.

Dois quilombos se destacaram na região vilabelense: Quariterê e Piolho. A população encontrada nos quilombos não se limitava somente a negros e escravos, mas também a índios e demais pessoas excluídas pela sociedade. Todas essas manifestações trazem e movem sentimentos até hoje na primeira capital de Mato Grosso, constituindo também a cultura recente (LIMA, 2000, p. 29).

Atualmente a população possui uma cultura ainda muito forte, permanecendo intacta desde sua origem pelos escravos. Sendo pouco explorada Vila Bela ainda compõe várias paisagens que juntamente as ruínas da antiga igreja matriz (construída pela coroa portuguesa) trazem turistas anualmente. A cidade faz manifestações de fé e cultura por meio de um grande evento de nível internacional. A famosa Festança, que engloba Festa do Divino Espírito Santo, a Santíssima Trindade e as Três Pessoas (padroeira do lugar), vem promovendo a cidade durante anos, trazendo um fluxo significativo de turistas, o que move grande parte do desenvolvimento e a economia da região.

A festividade ocorre de forma periódica, todo mês de julho no município, trazendo belas mostras cultuais passadas de gerações a gerações, como as rezas em devoção ao "Glorioso São Benedito", que visa proteger todo o Vale do rio Guaporé, a Dança do Chorado e a Dança do Congo, as bebidas afrodisíacas produzidas pelas mulheres mais 
antigas e também as comidas típicas, que neste período festivo é distribuída gratuitamente a toda a população (FACCHINETTO, 2009, p. 4).

A falta de infra-estrutura acaba por dificultar o êxito neste tipo de evento local. Não possuindo um lugar adequado às festividades ocorrem nas ruas, na pequena praça principal em frente à atual igreja, no singelo centro comunitário e nas casas dos "festeiros".

\section{FESTANÇA DE VILA BELA DA SANTÍSSIMA TRINDADE: MANISFESTAÇÃO DE FÉ E TRADIÇÃO}

Em Vila Bela da Santíssima Trindade, as crenças e práticas são ingredientes relevantes da formação comunitária, infiltrando-se nos acontecimento diários e no seu cotidiano concreto. Pinto (1950) (apud Bandeira, 1988, p. 183) conta como a força da fé dos negros já possuía grandes proporções: "A religiosidade dos pretos de Vila Bela já se chamou a atenção desde o século XVIII, surpreendendo os batedores do Quilombo do Piolho e do próprio Governador que se dispôs a batizar quilombolas, admirado na sua instrução religiosa.", sendo ainda discutida a expressão católica em conjunto a elementos de origens étnicas diversas:

\footnotetext{
Em linhas gerais a organização das crenças e práticas mágico-religiosas assume a feição do catolicismo rústico, identificado por Maria Isaura Pereira de Queiroz (1973:72-99) como expressão rural do catolicismo brasileiro que centra sua vida religiosa no culto dos santos. Em Vila Bela, esse culto assume feição heterodoxa, associando, como assinalou anteriormente, elementos de traços de diversas origens étnicas. (BANDEIRA, 1988, p. 183-184)
}

Segundo estudo de Lima (2000) a Festança está relacionada ao inicio do calendário agrícola, onde a terra era preparada para a semeadura, sendo realizada entre a segunda quinzena de setembro e a primeira de outubro, nos dois últimos meses da estação seca e a chegada da estação chuvosa. A celebração se baseava no agradecimento aos santos pela proteção da colheita anterior. Neste mesmo período aproveitavam para realizar as Festas de origem católica (festa de São Benedito) e 
africana (festa do Congo), sendo característica grandes refeições comunitárias envolto a grande consumo de alimentos.

A igreja aproveitava o momento de festas e o grande número de pessoas aglomeradas e ministrava suas visitas seguidas dos principais sacramentos da igreja católica, como batizados, casamentos, confissões etc. Dentre os acontecimentos da irmandade cristã as festas do calendário católico também ocorriam, somando à Festança a festa do Divino Espírito Santo, Santíssima Trindade, Nossa Senhora do Rosário e Mãe de Deus. Neste mesmo sentido demais festas e a dança do Chorado foram inseridos ao conjunto denominado Festança. Contudo os organizadores do evento decidiram mudar o período de festividade para a segunda quinzena de julho, pois coincidiria com o período de férias, trazendo um fluxo maior de visitantes (LIMA, 2000, p. 43-44).

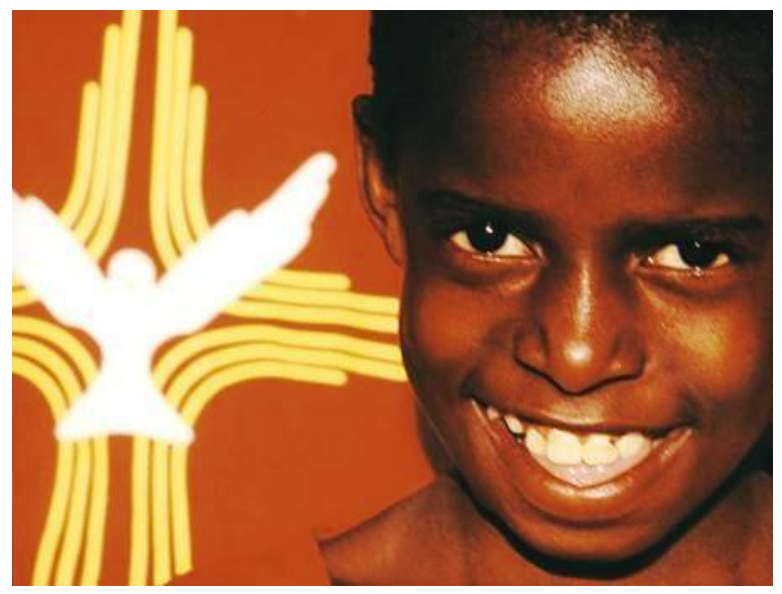

Figura 3: Festança de Vila Bela, junção da cultura negra e crença religiosa Fonte: VILELA, 2001.

\subsection{A PREPARAÇÃO E PEREGRINAÇÃO: FESTA DO DIVINO ESPÍRITO SANTO}

Lima (2000) afirma que a Festança de Vila Bela é iniciada com a Festa do Divino Espírito Santo, de acordo com a Festa de Pentecostes do calendário católico, realizado em maio ou junho. Sendo uma festa móvel, os preparativos ocorrem neste período, 
comandada pelos integrantes da irmandade do Divino, com o intuito de sua finalização na realização da festa, no terceiro domingo de julho.

Após as rezas e missas no domingo de Pentecostes, inicia-se a peregrinação da bandeira do Divino Espírito Santo em todas as residências da cidade (figura 4), a fim de arrecadar ofertas em prol da posterior festa (LIMA, 2000, p. 45).

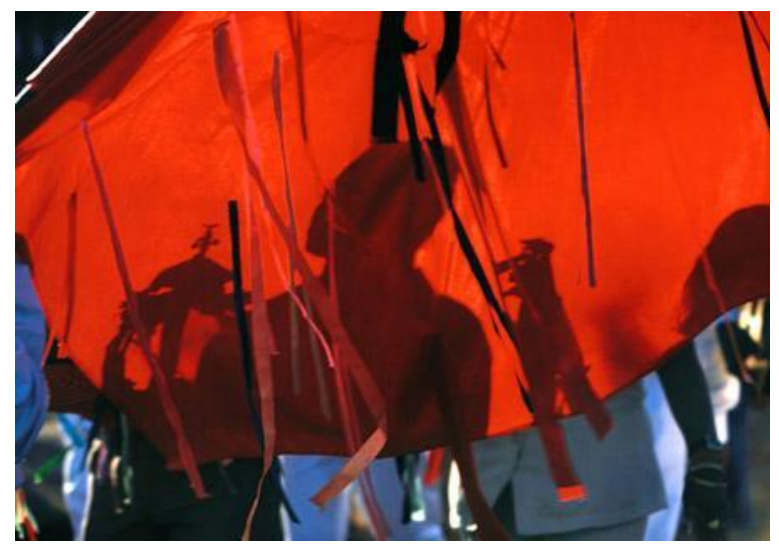

Figura 4: peregrinação da bandeira do Divino Espírito Santo Fonte: VILELA, 2001

Neste sentido a Festa do Divino suporta duas seqüências rituais: o primeiro consiste nos rituais preparatórios, marcados pela peregrinação da folia, as rezas, levantamento do mastro e alvorada dançante; e por ultimo os rituais propiciatórios, que consiste na reza solenes ou a missa, o sorteio dos novos festeiros e os banquetes (almoço e jantar) (LIMA, 2000, p. 45).

A peregrinação sempre se inicia na zona rural, tendo término na zona urbana, circulando pelos últimos quinze dias que precedem a Festança. Lima relata em um trecho de sua dissertação os responsáveis pela festa do Divino:

A festa do Divino Espírito Santo está sob a responsabilidade de dois grupos: o dos festeiros (Imperador, Imperatriz, Capitão do Mastro, Alferes da Bandeira, Mordomos e Procuradora da irmandade) e a folia do Divino. Esta é composta por seis foliões (adolescentes entre 13 a 17 anos responsáveis pelos cantos), um mestre que é o responsável pela iniciação dos foliões no grupo e pela execução do violão, um sanfoneiro e um fogueteiro, pessoa incumbida de soltar foguetes durante todo o período da peregrinação da bandeira até o dia da festa. Um dos foliões é o responsável pela execução da caixa. Os instrumentos utilizados pelos foliões são os seguintes: 01 violão, 01 caixa e 01 sanfona. Além dos instrumentos, fazem parte da folia também duas bandeiras (uma rica e uma pobre). A bandeira 
pobre é caracterizada por trazer na extremidade do suporte uma pombinha branca de madeira ou gesso, como símbolo do Divino Espírito Santo. Já a bandeira rica é caracterizada também por pombinha, mas confeccionada em prata. (LIMA, 2000, p. 46).

Todo o corpo integrante do Divino Espírito Santo leva a bandeira de casa em casa, trazendo proteção ao devoto do Divino, sendo a bandeira pobre quem entra na casa inicialmente, enquanto a rica, do lado de fora, espera a esmola do fiel para então poder se adentrar a residência. Lima (2000) ainda descreve o canto de solicitação da esmola ao dono da casa:

\author{
Divino pede a esmola \\ Não pede por carecer \\ Pede por experimentar \\ A quem seus devotos quer ser. (LIMA, 2000, p. 47).
}

Logo após os cantos e esmolas, o devoto do Divino oferece aos foliões uma confraternização onde são servidas bebidas como kanjinjin ${ }^{4}$ e biscoitos. Em seguida todos os foliões se conduzem a próxima casa, repetindo o mesmo ritual. O cortejo se encerra na igreja matriz, com ambas as bandeiras para então saudar o Divino Espírito Santo (LIMA, 2000, p. 47).

\title{
4.2 FESTA DE SÃO BENEDITO
}

Segundo dados de Lima (2000) a festa de São Benedito tem seu início no sábado que antecede a festa, a meia-noite, com uma alvorada dançante a partir do pátio da igreja. A população sai pelas ruas logo após a queima de fogos e o repicar dos sinos,

\footnotetext{
${ }^{4}$ Kanjinjin: é um licor afrodisíaco feito a partir de raizes e ervas do Vale do Guaporé sendo muito utilizado nas festividades de Vila Bela de origem religiosa (no mês de julho durante anos) que, juntamente com biscoitos também produzidos pelas mulheres vilabelenses, servia para repor as energias dos dançarinos da festa do congo, visto que eles começavam a dançar em todas as ruas da cidade às 04:00 e só paravam em torno de 21:00, quando posteriormente se juntavam aos bailes da festança. O nome kanjinjin é na verdade uma referência ao príncipe africano Kangingin, um jovem e forte guerreiro, com entre 14 e 16 anos, filho do rei do Congo.
} 
dançando e cantando do decorrer de toda a cidade, de casa em casa, seguindo o mesmo ritual já descrito da festa do Divino.

No fim da alvorada, é comum no domingo, por volta das 6 horas da manhã, os seresteiros tomarem o café da manhã na casa de um dos festeiros, saboreando uma quente sopa. De acordo com a citação a seguir, Lima descreve as atividades posteriores:

À noite, na seqüência das atividades pertinentes à festa, acontecem as rezas cantadas de São Benedito das residências do Rei, da Rainha, do Juiz e da Juíza. É um momento ritualístico-preparatório para grande festa. E para esse grande evento, os soldados dançantes do Congo entram em ação na madrugada do dia seguinte. $\mathrm{Na}$ segunda-feira, às $5 \mathrm{~h}$, um soldado do Congo, tocando bumbo, começa a percorrer a cidade com finalidade de chamar todos os dançantes do Congo. Um a um vai se juntando aos demais até que todos sejam convocados. O ultimo a integrar-se ao grupo é o Rei do Congo, estando o folguedo todo formado - o Rei do Congo, Príncipe, Embaixador, Secretário do Rei do congo e os 24 soldados dançantes - tem início o ritual do convite aos festeiros de São Benedito para participarem da missa. Todos os integrantes do Congo saem pelas ruas da cidade convidando os festeiros (a Juíza, o Juiz, a Rainha, o Rei e as Ramalhetes) - sempre nesta ordem -, para se dirigirem até a igreja matriz e participar da celebração da missa. (LIMA, 2000, p. 58-59).

A seguir Lima (2000) conta que os dançantes do Congo levam os festeiros para a missa e se despedem, permanecendo durante a missa na casa do dançante mais próximo. A figura 5 demonstra um dos dançantes em meio ao ritual pelo perímetro urbano.

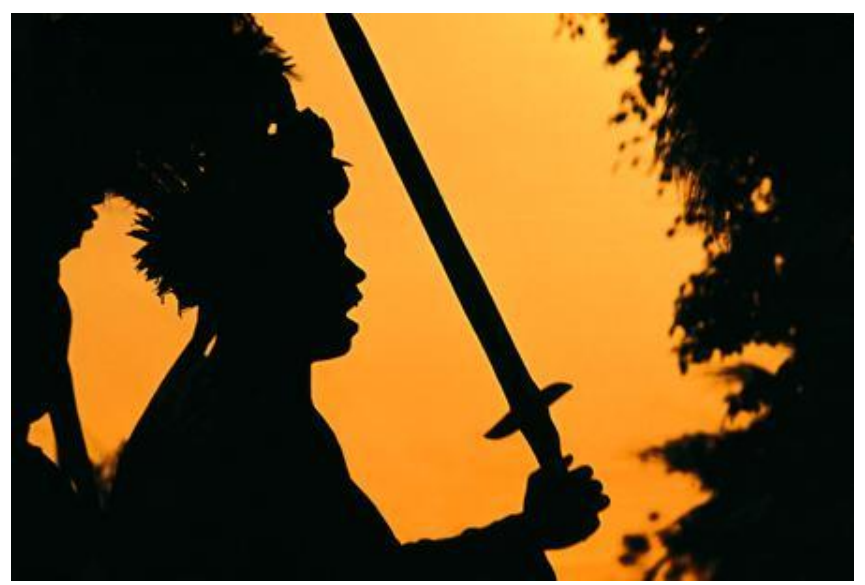

Figura 5: dançante do Congo

Fonte: VILELA, 2001 
A Dança do Congo mencionada por Lima será enfatizada na próxima seção neste capítulo.

\subsection{DANÇA DO CONGO}

Facchinetto (2009) afirma que a Dança do Congo é uma peça teatral feita a céu aberto, uma espécie de jogo, onde os personagens usam trajes coloridos e são devidamente armados com espadas de brinquedo. A história da dança ocorre ao redor de dois personagens principais: o rei do Congo, acompanhado por seu secretário de guerra e de seu filho Kanjinjin, e o rei Bamba, representado pelo seu exército, formado por 12 (doze) pares de guerreiros e por seu embaixador.

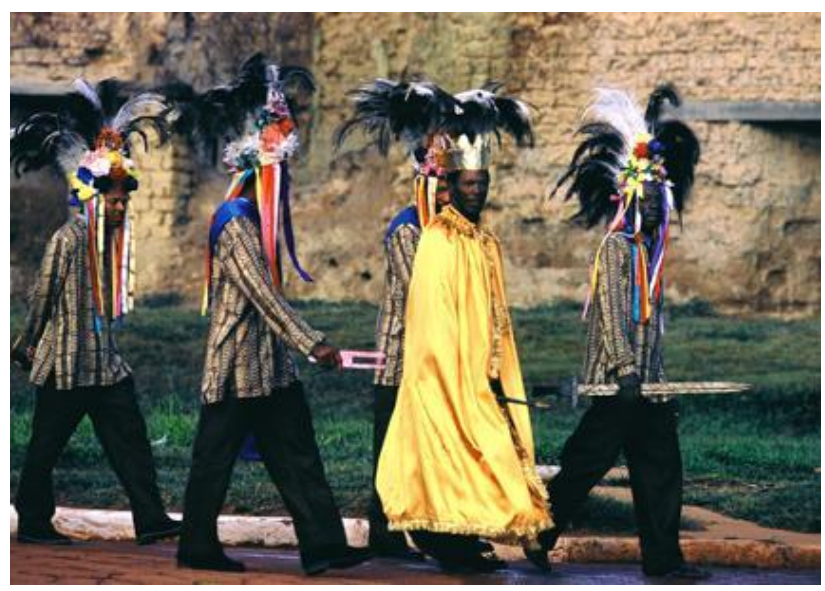

Figura 6: dançantes do Congo em frente as ruínas Fonte: VILELA, 2001

Começam então as encenações de uma guerra de 3 (três) homens contra 25 (vinte e cinco). Por fim, o vencedor desta batalha é o Rei do Congo, que se utiliza de magia africana, expressões e palavras para derrotar seus inimigos. Essa dança ajuda a sustentar a vivacidade da cultura de seus antepassados para seus antecessores.

Vilela (2001) mostra em um dos trechos de seu livro um dos cantos utilizados pelos dançantes da dança do congo:

"Sinhô Rei vamos embora,

Sinhô Juiz mando chamar

Sinhô Rei v amos embora 
Sinhô Juiz mandou chamar."

"Se a Rainha está sentada

Sem intenção de levantar

Se a Rainha está sentada

Sem intenção de levantar" (VILELA, 2001, p.78).

O trecho acima relata uma parte do canto dos dançantes onde a rainha, que está sendo escoltada até a missa, faz graça e tem todo o poder de parar a dança a hora que quiser se sentando em um banco que acompanha todo o trajeto. A festa é encerrada no final do dia, com a volta dos guerreiros para casa cantando as seguintes rimas (VILELA, 2001, p. 78):

\author{
"Acabou-se a festa \\ Com muita alegria \\ Acabou-se a festa \\ Com muita alegria \\ Viva Benedito Santo hoje neste dia \\ Viva Benedito Santo hoje neste dia" (VILELA, 2001, p.78).
}

\title{
4.4 DANÇA DO CHORADO
}

Segundo Facchinetto (2009) a dança do chorado é viva e sensual, é tida hoje como objeto de admiração e cerimônia cultural. A origem desta dança foi através de uma mágoa dolorida e profunda das mães e esposas escravas, que ao verem seus filhos e maridos castigados, ou jurados de morte, por feitores, utilizavam-se da dança para tentar livrá-los do infortúnio, atraindo a atenção dos patrões. O nome chorado, veio justamente dos choros dos que apanhavam e das escravas que assistiam.

Lima (2000) retrata como as mulheres faziam a dança do chorado:

[...] Reunidas em grupos, vestiam-se da melhor maneira possível e se dirigiam até as residências de seus patrões. Lá dançavam com algum objeto na cabeça (pedra, lata d'água, pedaço de madeira etc.) e um lenço amarrado no pescoço. Usavam de todos os movimentos possíveis do corpo para mostrarem sensualidade e destreza, como uma forma de agradar aos seus patrões e alcaçarem seus objetivos. Segundo informações prestadas por várias pessoas da comunidade, elas conseguiram ter vários pedidos atendidos (LIMA, 2000, p. 62). 
Atualmente o Chorado é marcado pela sedução, vestidos coloridos, passos compassados, ritmo constante, piscadelas insinuantes e um olhar de desafio constante. Esses olhares fazem com que o observador tenha uma sensação de inferioridade e submissão. No decorrer da dança, puxam uma garrafa de Kanjinjin e a colocam sobre a cabeça, sem perder o ritmo e o gingado. O equilíbrio demonstrado por elas as deixa ainda mais surpreendentes e exuberantes (FACCHINETTO, 2009, p. 5).

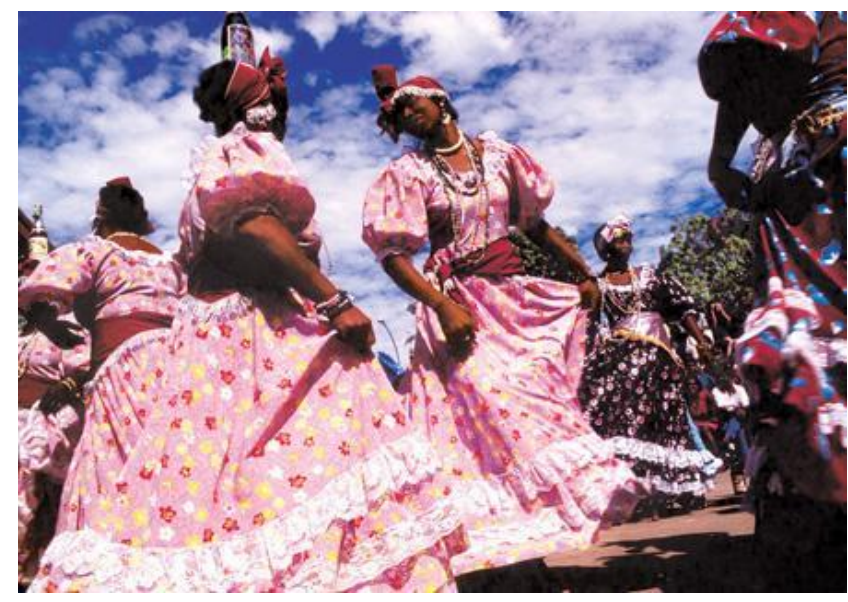

Figura 7: Dançarinas do Chorado Fonte: VILELA, 2001

Vilela (2001) indica um dos cantos utilizados pelo grupo do chorado:

"Morena, quem te contou

Que nesta noite sereno

Eu deitada no seu colo

Serenô, não me molho, morena

Era tudo que eu queria

Eu deitada no seu colo,morena

Tinha toda garantia

Mas que vim, que vim

Que vim, que vão

Mas que vim, que vim,

Que vim, que vão" (VILELA, 2001, p.60).

\subsection{FESTA DAS TRÊS PESSOAS}

Três Pessoas, ou Santíssima Trindade, é o santo padroeiro do município desde sua fundação. De acordo com Bandeira (1988), a igreja católica tinha a obrigação de 
celebrá-lo. A tradição foi mantida e a festa do padroeiro foi agregado a Festança. A festa das Três Pessoas é a última festa do ciclo, encerrando todo o evento. Os moradores acreditam que as Três Pessoas protegem o espaço geográfico da cidade, e assim indiretamente protegem a comunidade, onde a falta de devoção implica em algum castigo ao lugar, ficando sujeita a catástrofes e desastres. O santo por sua vez não interfere nas leis da natureza, mas pode controlar seus efeitos.

Os festeiros das Três Pessoas, Juiz e Juíza, são escolhidos pelos festeiros, sendo sempre um casal, que ficam encarregados das despesas integrais desta festa. Eles ficam responsáveis por organizar, acompanhar a alvorada e seresta durante toda a noite, patrocinando bebidas aos participantes. É também confiado a eles a limpeza e arrumação da igreja, locomoção do padre à missa, suprimento de fogos e velas, e principalmente o pedido constante de que haja muita fartura de bebidas e comidas, onde todos possam ser servidos igualmente (BANDEIRA, 1988, p. 244).

No domingo precedente à Festança, às 9 horas, ocorre na igreja matriz a missa solene animada pelo Coral da Consciência Negra, sendo esta a missa comemorativa da padroeira da cidade: Santíssima Trindade. É nela que também acontece a menção dos novos festeiros das Três Pessoas, que serão responsáveis pela festa do ano seguinte. Após missa costuma-se ser realizada uma procissão de apresentação dos novos festeiros a comunidade, findando no Centro Comunitário, onde é oferecido o almoço dos festeiros.

\section{CONCLUSÃO}

Como foi discutido, a disseminação da cultura e também crença religiosa, auxilia na busca de valores humanos, de cidadania e fé. É de supra importância a acreditar em algo maior que nós mesmos, que nos façam ter esperança, reafirmando a fé na santidade, por meio das manifestações, que trazem transformações dentro de nós mesmos.

Após todos os relatos concordamos que a Festança de Vila Bela da Santíssima Trindade é ainda um dos rituais mais singulares e belos de todo o estado de Mato Grosso. 
São memórias, por muitas vezes tristes de lutas dos antepassados negros, que não podem ser esquecidas, pois sempre que lembradas trazem a beleza e riqueza desta cultura.

A Festança é marcada por três celebrações de cunho católico (Festa do Divino Espírito Santo, Festa de São Benedito e Festa das Três Pessoas), que juntamente as outras duas celebrações de origem africana (Dança do Congo e Dança do Chorado), demonstram a trajetória do espaço geográfico e da população, de sua origem até a atualidade.

Segundo o depoimento da moradora Czarina Farias de Brito (assistente social da prefeitura de Vila Bela da Santíssima Trindade e presidente do Fórum das Entidades negras de Vila Bela da Santíssima Trindade) a Festança, seja por falta de infra-estrutura ou por desinteresse da população, têm sido esquecida e sua participação no turismo têm se reduzido.

Portanto é grande valia a conscientização da importância cultural de se manter suas origens e ritos tradicionais, conservando assim toda uma história, que envolveu tanta luta, dor e busca pelo espaço na sociedade.

\section{REFERENCIAS BIBLIOGRÁFICAS}

BANDEIRA, Maria de Lourdes. Território Negro em Espaço Branco. 1 ed. São Paulo: Brasiliense, 1988. $346 \mathrm{p}$.

CAVALCANTI, Lana; PAULA, A. M. Flávia. A cidade e seus lugares. 2007. Disponível em: <http://www.revistas.ufg.br/index.php/atelie/article/view/5343/4401>. Acessado em 15 de setembro de 2009.

COELHO, Paulo. Tradição Religiosa. 2007. Disponível em: <http://colunas.g1.com.br/paulocoelho/2007/06/25/tradicao-religiosa>. Acessado em 10 de junho de 2010. 


\section{Periódica Eletrânica

FACCHINETTO, Janaína. Arquitetura, cultura e tradição negra cultivadas há 252 anos. 2009. Disponível em: < www.arteecidade.ufba.br/p_JAF.pdf>. Acessado em 9 de setembro de 2009.

IBGE, Instituto Brasileiro de Geografia e Estatística. Vila Bela da Santíssima Trindade MT. 2007. Disponível em :

$<$ http://www.ibge.gov.br/cidadesat/xtras/perfil.php?r=2\&codmun=510550>. Acessado em 17 de outubro de 2009.

LIMA, José Leonildo. Vila Bela da Santíssima Trindade - MT: Sua Fala, Seus Cantos. Campinas, SP: UNICAMP, 2000. 232 p.

RODRIGUES, Sonia Regina Rocha. A importância da cultura na formação do cidadão. 2008. Disponível em: <http://www.qdivertido.com.br/verartigo.php?codigo=57>. Acessado em 19 de outubro de 2009.

VILELA, Mario. Festança de Vila Bela da Santíssima Trindade. 1 ed. Cuiabá, MT: M. Vilela, 2001. $96 \mathrm{p}$. 